\title{
The Prisoners' Rights Protection in Indonesia Law System of Justice
}

\author{
Haidan ${ }^{1 *}$ \\ Edy Santoso 1 \\ ${ }^{1}$ Ministry of Justice and Human Rights of the Republic of Indonesia \\ Agency for Human Resources Development and Human Rights Law \\ *Corresponding Author, Email: haidan017@gmail.com
}

\begin{abstract}
:
The aim of the paper is to examine the provision of the prisoner's rights protection in Indonesia law system of justice and its relation to the exemption conditional (EC) in correctional institution. As an important issue, here is if the defendant override rules associated with the controversial issue in society, they will both at national and international level, such as human rights issues. The case was appeared recently, especially in the connection with the cases of exemption conditional, i.e. Pollycarpus Budihari Priyanto's case. The case has become the center of public attention, especially after release of the Ministry of Law and Human Rights, who has been freeing the prisoners that related to the homicides Human Rights Activists (HRA) i.e Munir Said Thalib. In the community, this decision raises the pro and contra. This paper concludes that all persons deprived of their liberty will be treated with humanity and guaranteed them with respect for the inherent dignity of the human person to be in accordance with the existing rules. In this case, the government of Indonesia has given the rights of prisoners through the stages of development of the inmates according to the stage of the penal process that refers to laws and regulations and implementation of technical regulations. The paper also recommends that the need for the government to deliver data either traditionally or electronically linked plan of exemption conditional.
\end{abstract}

Keywords: Prisoner, Human Rights, System of Justice, Penal Law, Humanity, Dignity.

\section{A. INTRODUCTION}

Recently the Ministry of Justice and Human Rights, RI become a byword in the case of parole Mr. Pollycarpus. Since November 29, 2014, convicted of the murder of Human Rights (HAM) Munir Said Thalib had obtained parole based on the Minister of Justice and Human Rights W11.PK.01.05.06.0028 No. 2014 dated November 13, 2014. This decree provides the legal basis to Pollycarpus to be able to breathe and gain coaching outside Penitentiary.

In this case. Director General of Corrections, Ministry of Law and Human Rights believes that the person concerned is considered to be eligible for parole. In the community, the decision to get the pros and cons. Human rights activists are disappointed with the parole given to the convicted murder of the activist. Among them, the NGO Imparsial was disappointed with the government decision to allow bail to Pollycarpus. The decision seemed to dashed hopes of the people who want investigated the death of human rights activist, Munir Said Thalib, up to the full (Republika.co.id, Jakarta. Accessed 31 December 2014). 
Pollycarpus eligible for parole after serving eight years of a sentence of 14 years in prison sentence handed down against the Supreme Court. Pollycarpus was found guilty in the death of Munir on the plane Garuda Indonesia, ten years ago.

To the decision on granting parole, the Solidarity Action Committee for Munir (KASUM: Komite Aksi Solidaritas untuk Munir) will do a subpoena to the president. Meanwhile, the claim is to revoke the granting of parole to convict the murder of human rights activists, and hope the President can consider to revoke the parole. According to Chief of General Staff, very unfortunate if the president gets a subpoena (Tribunnews.com, Jakarta. Accessed 31 Desember 2014).

Granting parole to convict, making the most elements of society who care about human rights to feel disappointed. In fact, they look forward to the president to be able to reopen the case and investigate the mastermind killer to be brought to justice. Given all this time, the main actors human rights activist killers are yet to be revealed.

Related to these polemics, the Ministry of Justice, had asked the Head Office of the Ministry of Justice and Human Rights and Prosecutor's West Java, as the competent institutions in the area of Bandung Sukamiskin Penitentiary, to provide information in a press conference. This needs to be done in order, the public better understand the real issues related sitting issuance of the decision on granting parole.

Meanwhile, the Ministry of Justice and Human Rights requested that all elements of society to respect the rights of prisoners, let alone convicted Pollycarpus was not included in the category of prisoners stipulated in Government Regulation No. 99 Year 2012 on Tightening Remission. In this case, the rejection of the request for parole for prisoners who are eligible are his rights. Thus, the refusal will only contrary to human rights. In legal terminology in the System Corrections, Parole is a training ground for the inmates who had run $2 / 3$ of his criminal past. Parole is the process of coaching beyond Correctional Institution inmates held under Article 15 and Article 16 of the Code of Criminal Law and Articles 14, 22 and Article 29 of Law No. 12 of 1995 concerning Corrections (Keputusan Menteri Kehakiman Republik Indonesia Nomor M.01.PK.04-10 Tahun 1999).

Provisions concerning the terms and procedures for the implementation of the rights of inmates, as mandated in the Act - Act No. 12 of 1995 concerning Corrections and based on Government Regulation No. 32 of 1999 on the Terms and Procedures for Citizens Rights Patronage Correctional jo. Government Regulation No. 28 Year 2006 regarding Amendment to Government Regulation No. 32 of 1999 on the Terms and Procedures for Citizens Rights Patronage of Corrections and Regulation of the Minister of Justice and Human Rights of the Republic of Indonesia Number: M.01.PK.04-10 of 2007 on the Terms and Procedures for Assimilation, Parole, Leave By the Free and Conditional Leaves.

The setting of prisoners' rights should also refer to the international human rights according to the agreement, for each country, are obliged to respect human rights law, without exception. With the establishment of international law on human rights, the collective guarantee for the protection and fulfillment, automatically continue to be developed. International jurisprudence, also encouraging, it also provides limits of national jurisprudence that does not deviate much from the general legal principles accepted (Instrumen Internasional Pokok Hak Asasi Manusia, 2006). 
In explanation of Law Number 12 Year 1995 regarding Correctional states that the penal system is a continuum of criminal law enforcement, and therefore its implementation can not be separated from the development of general conception of the criminal prosecution.

Inmates are not only objects but also subjects that do not differ from other human subject can make mistakes or negligence that may be subject to criminal, so it does not have to be eradicated. The most important thing here is to be eradicated are factors that can cause the inmate to do things that are contrary to law, morals, religion, or social obligations other liability which may be subject to criminal.

Punishment is an attempt to sensitize inmates to be regretted, and return them become good citizens, obey the law, uphold moral values, social and religious, in order to achieve a society that is safe, orderly, and peaceful (UU No. 12 Tahun 1995).

Based on the above background, the authors try to do research with the title "prisoners' rights relating to granting parole" for purposes of the development of scientific knowledge and an understanding of the passage of the process of granting parole in the correctional system.

Based on the description above, several problems arise and become the framework for preparing the authors of this paper.

The problem that needs to be formulated as follows:

1. Does parole convicted Pollycarpus as the killing of Munir Said Thalib, in accordance with statutory regulations?

2. What makes up the considerations that may affect the assessment of decision on granting parole to a convicted?

\section{B. METHODS}

The method used is descriptive method, the method of scientific research that is based on inductive thinking groove in approaching scientific truth. The inductive thinking associated with the development of generalization of the results of specific observations. In other words, the research methods that will be done is descriptive-analytic.

Flow thinking consists of three steps: (1) Observation, is to do a careful monitoring or object of study, (2) discovery of patterns, are finding various patterns associated with the object of research, and (3) The conclusion, temporary tentative is to draw conclusions from various circuits and patterns of objects. This research was conducted by way of describing the process of granting parole was associated with Law No. 121995 at the Correctional Institution Class I Sukamiskin, Bandung - West Java.

Types of data collected is:

a. Act 12 of 1995 concerning Corrections;

b. Data on the implementation of granting parole at the Correctional Institution Class I Sukamiskin, Bandung - West Java;

In this study the data sources needed are as follows: 
The primary data source, namely the respondent in this case is the Head of Development Penitentiary Sukamiskin Class I, section head of the Community Guidance, Staff Prisons and Prisoners who have been undergoing training for over 5 years.

Secondary data source, the data support the primary data and the problems studied. This data was obtained from the literature that certain parts of the books, papers, and others that are related to the problems examined.

Data collection techniques used in the form of a blend of field technique and library studies.

\section{RESULT AND DISCUSSIONS}

\section{General Review on the Rights of Prisoners and Parole}

\section{a. Rights of Prisoners}

One of the aims of the Indonesian State Constitution (UUD 1945) is to protect the entire Indonesian nation and the entire country of Indonesia. The purpose of the destination country that protects and covers the entire nation entirely. So, the country overcome all groups understand, overcome all know individuals. State, according to the definition of "opening" it wants the union covering the entire Indonesian nation entirely (UUD 1945).

Nation, essentially made up of human beings, in the sense of political nations is a society that is in an area or region are the same and they are subject to the sovereignty of the country as a supreme power out and into. Human beings in a country having separate groups, this organization must be protected, including a group of Prisoners.

Prisoners according to Law No. 12 of 1995 concerning Corrections chapter one (1) Paragraph Seven (7) is undergoing criminal offenders lost its independence in prisons. Paragraph six (6) the convicted person is a person who is liable under a court decision which has obtained permanent legal force. The fact Prisoners are people who have been found guilty by a court decision, however, only human who has certain rights which continue to cling to him while he was alive.

A Chapter X of the 1945 Constitution on the second amendment on Human Rights contains several provisions concerning the rights of Prisoners, namely:

Paragraph D of Article 28 (1)

"Everyone has the right to recognition, security, protection, and legal certainty and equal treatment before the law"

In addition, Article 28 I Paragraph (1) also states that:

"The right to life, freedom from torture, freedom of thought and conscience, freedom of religion, freedom from enslavement, recognition as a person before the law, and the right not to be prosecuted based on retroactive law is a human right can not be reduced under any circumstances"

All matters relating to the protection and then set back in the Act are further regulated as mandated in Article 28 I paragraph (5), namely: 
"To uphold and protect human rights in accordance with the principles of a democratic constitutional state, the exercise of human rights is guaranteed, regulated, and set forth in the legislation".

The mandate of the 1945 Constitution, it then becomes a reference issued by the Law of the Republic of Indonesia Number 12 of 1995 concerning Corrections. Basic considerations issued this Act that essentially the Citizens Patronage of Corrections as a human being and human resources should be treated well and humanely in one integrated guidance system (Undang-undang Republik Indonesia Nomor 12 Tahun 1995).

Enforcement of inmates with good and humane stipulated in this Law, correctional guidance system is implemented based on the following principles:
a. Aegis
b. Equality of treatment and care
c. Education
d. Guardianship
e. Respect for human dignity
f. Loss of independence is the only suffering, and
g. Ensuring the right to maintain contact with families with certain people (Pasal 5 Undang Undang No. 12 Tahun 1995).

In addition, article 14 mentioned Prisoners are also entitled to:
a. worship according to religion or belief
b. treatment, both spiritual and physical care
c. get an education and teaching
d. health services and decent food
e. file a complaint
f. get reading materials and following other mass media broadcasts that are not prohibited
g. a wage or premium for work performed
h. receive family visits, legal counsel, or another particular person
i. get a reduction in criminal past (remission)
j. get a chance to assimilate including home leave
k. parole
I. getting off work nearing release, and
$\mathrm{m}$. acquire other rights in accordance with the legislation accepted.

Then, Article (2) says:

"The provisions concerning the terms and procedures for the implementation of the rights of inmates referred to in paragraph (1) shall be regulated further by a government regulation".

It is then governed by the Indonesian Government Regulation No. 32 of 1999 on the Terms and Procedures for Correctional Citizens Rights Patronage accordance with the mandate of Article 2 of Law No. 12 of 1995. The setting of the inmate rights should also refer to international human rights, for each country, are obliged to respect human rights law, without exception.

By establishing of international human rights law, the collective guarantee for the protection and fulfillment, automatically continue to be developed. International jurisprudence, also encouraging, it 
also provides limits of national jurisprudence that does not deviate much from the general legal principles accepted (Ake Arif, 2006: 11).

Besides that, the International Prisoners regulation of rights stipulated in the Standard Minimum Rules for The Treatment of Prisoners and article 7 of the Convention on civil rights and political.

In the Standard Minimum Rules for The Treatment of Prisoners agreed upon by the Congress of the United Nations in Geneva, 1995, Approved Economic and Social Council in 1957, noted some of the inmates rights, namely:

1. Access to court

2. Propection from cruel and unusual

3. Civil rights

4. Protection of rights in decisions when adverse consequwnces are possible

Also, concerning the protection of the rights contained in the convention Prisoners also civil rights and politics. Civil rights and political rights are derived from the inherent dignity and of the human person are guaranteed and respected by the Government so that people are free to enjoy the rights and freedoms in the field of civil and political (http//www.hukumham.info). Article 10 of the convention states.

Every person deprived of liberty shall be treated with humanity and with respect for the inherent dignity of the human person.

1. The suspect, except in circumstances very specific, should be separated from those who have been convicted, and to separate treatment appropriate to their status as unconvicted persons;

2. Accused juvenile persons shall be separated from adults and brought as speedily as possible for adjudication.

3. The correctional system should have the main purpose of reformation and rehabilitation in treating inmates. Juvenile offenders shall be segregated from adults and be accorded treatment appropriate to their age and legal status (Konvenan Internasional Hak-hak Sipil dan Politik).

As for the obligation to protect the rights of civil and political rights of citizens in accordance with Article 8 of Law No. 391999 affirmed that the protection, Promotion, Enforcement and fulfillment of human rights is primarily the responsibility of government (Konvenan Internasional Hak-hak Sipil dan Politik).

From both these laws, both national and international sources of law concerning the protection of human rights Prisoners may became a reference to the protection of human rights Prisoners.

\section{Inmate Guidance Stages}

In general, of prisoners coaching aims to enable them to become fully human as has been the direction of national development through approaches:

a. Confirming of their faith (mental toughness).

b. Coach them to be able to interact naturally in the life of the group over the Penitentiary and broader life (community) after undergoing criminal. 
In particular, guidance is intended to allow of prisoners during and after the development is finished running its criminal past:

a. Successfully re-establish self-esteem and confidence and optimism about the future.

b. Successfully acquire knowledge, skills for the provision of at least able to live independently and participate in national development activities.

c. Successfully become law-abiding man who reflected on their attitudes and behavior orderly discipline and be able to raise a sense of social solidarity.

d. Successfully has a soul and a spirit of service to the nation and the state (Keputusan Menteri Kehakiman Republik Indonesia Nomor: M. 02-PK.04.10 Tahun 1990).

Based on the Circular No. KP.10.13 / 3/1, dated February 8, 1965 of the Penal As a process, it can be argued that fostering adult inmate executed through four (4) phases, which is a unified process that is integrated, including:

\section{a. First Step}

For any inmate who entered at the Correctional Institution to investigate all matters concerning him, including the causes of inmate commits an offense and any information about themselves that can be obtained from family, former employers or superiors, fellow workers, the victim of his actions, as well of officers' other agencies that have handled his case.

Guidance at this stage is called formation early stage, in which the future activities of observation, research and introduction of environment to determine the planning of program implementation personality development and independence which time started at the time in question the status as Prisoners of up to $1 / 3$ (one third) of its criminal past. Guidance at this stage was done in Prisons and control the maximum (maximum security).

\section{b. Second Step}

If the training ground for the inmate in question had lasted for one third of the actual criminal past and by Correctional Observer Team had achieved considerable progress, among other things showed conviction, improvement, discipline and abide by the discipline rules accepted at the Correctional Institution, then Inmates concerned to be given a lot more freedom and placed on Prisons through medium-security surveillance.

\section{c. Third Step}

If the coaching process of Prisoners have undertaken $1 / 2$ (half) of the criminal past actual and according to Correctional Observer Team has achieved considerable progress, both physically and mentally and also in terms of skills, the container process of fostering an expanded program Assimilation whose implementation consists of 2 (two) parts, including:

a) The time starts from the end of the initial phase of up to $1 / 2$ (half) of its criminal past. At this stage, coaching is still held in the Penitentiary and supervision has entered the stage of medium-security.

b) At this stage the time starting from the expiration of the first advanced up to $2 / 3$ (two thirds) of its criminal past. In this advanced stage Inmates already entered the stage of assimilation, and therefore could be given parole or Leave By the Non-security with minimum supervision. 


\section{d. Fourth Step}

If the coaching process has undergone $2 / 3$ (two thirds) of the actual criminal past or at least nine (9) months, this coaching is called the final coaching stage which activities such as planning and implementation of integration programs started towards the end advanced stages until the end criminal past of Prisoners concerned. Guidance at this stage of Prisoners who are qualified to be given Leave By the Free or parole and fostering carried out by the Central Penitentiary Correctional then called Client Correctional Supervisor. guardianship is the provision of guidance to improve the quality of devotion to God Almighty, intellectual, attitude and professional behavior, physical and spiritual health Correctional Client.

According to Adi Sudjatno scope of coaching based on the Ministry of Justice of the Republic of Indonesia No. M.02-PK.04.10 1990 on the Guidance Pattern Inmates can be divided into two (2) areas, namely (Keputusan Menteri Kehakiman Republik Indonesia Nomor: M. 02-PK.04.10 Tahun 1990):

1. Personality Guidance which includes, including:

a. Religious consciousness guidance.

b. The state and nation guidance.

c. Intellectual abilities (intelligence) guidance.

d. Awareness of the law guidance.

e. Integrate themselves with society guidance.

f. Autonomy guidance provided through programs, namely:

g. Skills to support independent businesses, such as handicrafts, household industry, repair machinery and electronic equipment, etc.

h. Skills to support small industry, for example, the management of raw materials from agriculture and natural materials into semi-finished materials and into finished materials.

i. Skills are developed in accordance with the talent of the inmates respectively.

j. Skills to support the efforts of industrial or agricultural activities (plantation) technology using intermediate or high-tech, such as leather industry, textile mills and so on.

Aside from the Guidance Patterns convict based on the Ministry of Justice of the Republic of Indonesia No. M.02-PK.04.10 1990 on the Prisoners Guidance Pattern, then according to Adi Sujatno there are fundamental elements in supporting the coaching of interest in the penitentiary system, including:

1. Inmates themselves.

2. The officers / employees of Penitentiary.

3. Society, in this case that includes government agencies and private institutions, social organizations, families of inmates themselves.

As for the prisoners, based on the Ministry of Justice of the Republic of Indonesia No. M.02-PK.04.10 1990 on the Prisoners Guidance Patterns in Chapter VII of the Implementation Guidance detainee stating that the form coaching, including:

1) Detention Services.

a. The legal assistance. 

b. Spiritual counseling.
c. Extension physical.
d. Talent guidance.
e. Skills guidance.
f. Library.
g. The things that must be considered in carrying out guidance activities.

2) Guidance Prisoners and Protégé.
a. The stages of coaching.
b. A form of coaching.
c. Guidance of Prisoners who receive special attention.

3) Guidance Client.
a. The stages of guidance.
b. Approach guidance.
c. Form of guidance.

\section{Analysis of Legal Rights of Prisoners and Parole}

Parole to convicted murder of human rights activist Munir Said Thalib, Pollycarpus, in accordance with statutory regulations.

As described above, by corrections, inmates who entered the first examination of the letter and detention, namely Decree (Extra Verdict) Judge, it is to facilitate the calculation when the inmates will undergo stages of development as well as determining the rights to the prisoners got Assimilation, the Parole, Towards Free or Conditional.

To get parole, which must be met by residents of Corrections proposed Patronage granted parole or Voorwandely Invrijdsteling (VI) and leave Toward Free means should qualify substantive namely the implementation of assistance programs implemented properly and diligently and never get disciplined. In addition to the requirements subsantif to be met by a citizen Patronage of Corrections is admin requirements must also be met as well as the Research Community, a guarantee letter from the family signed by the family over the seal or paper stamped, known to the Neighborhood and the Village Head or Head Village where the Guarantor and the Correctional Patronage Citizen domiciled or residing. In addition to the above for Citizens Patronage of Corrections to be given parole must be a declaration of the State Attorney where residents Patronage of Corrections convened stating that he had no other cases that have not been disconnected.

As for the purpose of parole for inmates is to facilitate their return to society (resocialization), as well as to motivate citizens Patronage of the Penal good behavior during his criminal past in the Penitentiary. Understanding of the Parole, was the one who was jailed be released with the agreement, if it has then two thirds of the sentence is true and also at least nine months (KUHP).

Parole different to leave ahead of the free and off parole, furlough nearing release is not intended to put an end to the punishment, because the inmate and protege correctional (except children civilian) who has completed a time off towards free and leave conditional will return to the Penitentiary to finish his term, while aiming to end parole punishment (Peraturan Menteri Hukum dan Hak Asasi Manusia Republik Indonesia, 2007). 
Correctional Centres through the role of Community Advisors make sustainable plan in cooperation with the Penitentiary (Prison), doing research community. So, the social research conducted since jail term is executed, it can be used to determine the right coaching program for prisoners. Community mentors can play a role to explain stage phase that will pass while serving time in prisons and the rights owned in coaching such as parole, conditional time off, free to time off ahead of the final stages in the coaching and ongoing treatment program after his release (Moch. Sueb dkk., 2008).

Parole according to the Indonesian Government Regulation No. 32 of 1999 on the Terms and Procedures for Citizens Patronage of Corrections, stated that: Parole is a training ground outside Penitentiary inmates after serving at least $2 / 3$ (two thirds) of the criminal past of at least nine (9) months, then coaching in this stage enters the final stages of development, namely in the form of planning and implementation of integration programs initiated since the end of the advanced stage until the completion of criminal past. At this stage, for prisoners who are eligible granted leave nearing release or parole, coaching is done outside the prison by Correctional Center then called Coaching Client Correctional.

Implementation of the Parole at the Correctional Institution Class I Sukamiskin not without obstacles, whether it is internal resistance that occurs, especially as one example of the prisoners and protege correctional itself, which often does not support the implementation because it does not show attitude and good behavior, as well as notification and request by the social researcher prisons are not well coordinated so that the delay in the process to obtain parole. While external obstacle is a suspicion of a number of community-related abuses of power by local officials have, in the stages of its development process, as well as their concerns about security threats.

The authority in granting parole, leave nearing release and conditional leave, based on the Minister of Law and Human Rights No. 01. M. PK. 4:10 Year 2007 on Terms and Procedures for Assimilation, Parole, Leave Towards Free, And leave is conditional, namely the Head Office of the Ministry of Justice and Human Rights locals on behalf of the Minister of Justice and Human Rights to Leave By Free or leave is conditional and the Director General of Corrections for Convicts and Learners of Corrections who had been convicted of a criminal offense as stipulated in Government Regulation No. 28 Year 2006 regarding Amendment to Government Regulation Number 32 of 1999 on the Terms and Procedures for the Implementation of the Right People Patronage of Corrections after obtaining approval from the Minister of Law and Human Rights Republic of Indonesia to the Parole.

\section{Elements considerations that may affect the assessment of the decision to grant parole to a convicted person.}

The fulfillment of the substantive requirements and administrative requirements, as follows:

1) The substantive requirements:

a. Inmates have shown awareness and remorse for the mistakes that led to sentenced.

b. Inmates have shown good character development and positive moral.

c. Inmates successful program development activities diligently and eagerly.

d. Communities can receive program development activities criminal prisoners and children are concerned.

e. Good behavior for a sentence and never got disciplinary punishment at least within nine (9) months. Criminal past who have endured 2/3 (two thirds) of the criminal past, provided that $2 / 3$ (two thirds) of the criminal past of not less than nine (9) months. 
2) The administrative requirements:

a. A copy of the judge's verdict (verdict extract).

b. Social research report made by Supervising Social or fostering progress report and protégé correctional inmates made olehWali Corrections.

c. The notification to the District Attorney about the plan of assimilation, parole, furlough nearing release, and leave conditional on correctional inmates and students concerned.

d. A copy of the register $F$ (a list that includes about violations of the discipline, inmates and correctional protégé during his criminal past) of the Head of Penitentiary (Prison) or the Head of the House of Detention (Rutan). A copy of the list of changes or reduction in criminal past, such as pardon, remission, and others from the Chief or Chief Prison and Detention.

e. Letter of intention of the parties will accept inmates and correctional protégé, such as the family, schools, government agencies or private to be known by the local government as low headman or village head. For children of prisoners or criminal foreign nationals required additional terms in the form of a letter of guarantee from the Embassy / Consulate of the State the foreign national and a letter from the head of the local Immigration Office regarding immigration status is concerned.

3) Parole to convicted Pollycarpus Budihari Priyano.

a. The process of ordinary criminal law and excluding the extraordinary crime (Extraordinary crime), convicted Pollycarpus not included in the category of prisoners stipulated in Government Regulation No. 99 Year 2012 on Tightening Remission.

b. Hopes for disclosure against the alleged intellectual authors behind the death of human rights activist Munir Said Thalib was a law enforcement must continue to be done regarding this matter, not the authority of the Ministry of Justice and Human Rights.

As the Law of the Republic of Indonesia Number 8 of 1981 on the Law of Criminal Procedure Chapter I General Provisions Article 1 number 1, 2, 3, 4, 5 states:

1) The investigator is a police officer or official of the Republic of Indonesia of certain civil servants are given special authority by law to conduct investigations.

2) Investigation is investigating a series of actions in terms and in the manner set forth in this law to find and collect evidence with evidence that shed light on the crime happened and to find the suspects.

3) Investigators maid was a police official for the Republic of Indonesia which was given certain powers can perform the duties of investigation stipulated in this law.

4) The investigator is a police officer of the Republic of Indonesia which is authorized by law to conduct an investigation.

5) The investigation is a series of actions of investigators to search for and find an event alleged criminal acts in order to determine whether or not the investigation in the manner set forth in this law.

Then it was lit on disclosure of the mastermind behind the death of the human rights activists are in the authority of the Republic of Indonesia police forces to conduct investigations and examinations as part of the law enforcement process should continue to run in accordance with the legislation. 


\section{The minutes of Calculation Expirasi and Parole a.n Pollycarpus}

Considerations about granting parole according treatise Expiration calculation and Parole on behalf of the convicted Pollycarpus is as follows:

a. Verdict I (Class I Cipinang Prison)

Based on the Central Jakarta District Court No. 1361 / Pid.B / 2005 / PN.Jkt.Pst dated December 20, 2005, with details as follows:

$\begin{array}{ll}\text { Full Name } & : \text { Pollycarpus Budihari Priyanto } \\ \text { Case } & : \text { Murder } \\ \text { Article } & : \text { Article } 340 \text { of Law on the Penal Code } \\ \text { Start date detained } & : 19 / 03 / 2005 \\ \text { Date of Verdict } & : \text { 20/12/2005 } \\ \text { punishment } & : 14 \text { Year } \\ \text { Expiration } & : 19 / 03 / 2019\end{array}$

4. Verdict II (Class I Cipinang Prison)

Based on the Jakarta High Court (Appeals) No. 16 / PID / 2006 / PT.DKI dated March 27, 2006, with details as follows:

Full Name

Pollycarpus Budihari Priyanto

Case

Murder

Article

Article 340 of Law on the Penal Code

Start date detained

$19 / 03 / 2005$

Date of verdick

$27 / 03 / 2006$

punishment

4 Year

Expiration

$19 / 03 / 2009$

5. Verdict II (Class I Cipinang Prison)

Based on the Verdict of the Supreme Court (cassation) Number. 1185.K / Pid. / 2006 dated October 3, 2006, with details as follows:

\begin{tabular}{|c|c|}
\hline Full Name & Pollycarpus Budihari Priyanto \\
\hline Case & Murder \\
\hline Article & Article 340 of Law on the Penal Code \\
\hline Start date detained & $19 / 03 / 2005$ \\
\hline Date of verdick & 03/10/2006 \\
\hline punishment & : 2 Year \\
\hline originally expiration & : 19/03/2007 \\
\hline Total Remission & : 3 Month \\
\hline actual expiration & ; 25/12/2006 \\
\hline
\end{tabular}

d. Verdict IV

Based on the Verdict of the Supreme Court (Reconsideration I) Number. 109.PK/Pid/2007 dated 01/25/2008, with details as follows:

Full Name

: Pollycarpus Budihari Priyanto

Case

Murder

Article

: Article 340 of Law on the Penal Code

Date of verdick

: 27/03/2006

Punishment

: 20 Years - 2 year (Has been undertaken by the

Start date detained verdict III) $=18$ Years

Actual expiration

: 25/01/2008

: $25 / 01 / 2008$ 
Total remission

Actual expiration
51 month 80 days

$29 / 08 / 2021$

e. Verdick V

Based on the Verdict of the Supreme Court (Reconsideration II) Number. 133.PK/Pid/2011 Date 01/10/2013, with details as follows:

\begin{tabular}{|c|c|}
\hline Full Name & Pollycarpus Budiha \\
\hline Case & Murder \\
\hline Article & Article 340 of Law \\
\hline Date of Verdict & 02/10/2013 \\
\hline Punishment & 14 Tahun \\
\hline $\begin{array}{l}\text { Start date detained } \\
\text { (Execution date) }\end{array}$ & $25 / 01 / 2008$ \\
\hline originally expiration & 25/01/2022 \\
\hline Total Remission & 51 Month 80 days \\
\hline actual expiration & 29/08/2017 \\
\hline Date. $1 / 3$ criminal past & 04/04/2008 \\
\hline Date. $1 / 2$ criminal past & 03/08/2010 \\
\hline Date. $2 / 3$ criminal past & $30 / 11 / 2012$ \\
\hline
\end{tabular}

Based on these calculations, $2 / 3$ date falls on 11.30.2012. Obtained their parole by the Minister of Law and Human Rights No.: W11.PK.01.05.06-2008 2014 November 13, 2014 On Parole Prisoners. Then SK received from the Regional Office of the Ministry of Justice and Human Rights western Java on 26th November 2014 and the implementation of the PB held on 29 November 2014 at the request concerned (Data Sekunder LP Kelas I Sukamiskin Bandung).

\section{CONCLUSION}

Based on the above description of the "Rights of prisoners defendants associated with granting parole at the Correctional Institution Class I Sukamiskin Bandung West Java", the authors can obtain the following conclusion every person deprived of liberty shall be treated with humanity and with respect for the inherent dignity of the human person, in this connection Correctional Institution Class I Sukamiskin has given the rights of prisoners through the stages of formation of the convicted murder of human rights activist Munir Said Talib, Pollycarpus and in accordance with the stages of the correctional process with reference to the laws and regulations and implementation of technical regulations. The element of consideration is the fulfillment of requirements Substantive and administrative requirements to obtain parole for a convict. Then convicted Pollycarpus has undergone stages of the process of coaching at the Correctional Institution, for $2 / 3$ the actual criminal past, then coaching in this stage enters the final stages of development, namely in the form of planning and implementation of integration programs started towards the end advanced stages up to completion criminal past. At this stage, prisoners are eligible granted leave nearing release or parole.

In this section, the authors submit the following recommendations for prison Class I Sukamiskin Bandung West Java in order to continue and further enhance the guidance so that the purpose of the grant of parole is actually achieved. One effort in order to achieve these goals is to be published as a form of communication early to all elements of society, through the establishment / or the appointment of a spokesman of Corrections to publish on their websites / electronic media and print media, in order to avoid misunderstandings interpretation by the stakeholders, Related measures 
steps taken in the process of providing guidance to prisoners by the Directorate General of Corrections.

The government and the House of Representatives (the Ministry of Justice and law experts and the authorities) to formulate and review legislation and Technical Regulations Implementing the activities of the organization of the penal order of effectiveness, and transparency of the prison as a guidance to inmates in accordance with the purpose state protects the entire Indonesian nation and the entire country of Indonesia can be achieved, and can satisfy the justice of the demands of society. 


\section{References}

Civil Rights and Political Rights Research and Development Agency Department of Law and Human Rights, http://www.hukumham.info International Covenant on Civil Rights and Political.

Hak-hak Narapidana, (Accessed 31 Desember 2014) Sap 3, Recap by Iqrak, https://www.google.com/?gws_rd=ssl\#q=Hak-hak+Narapidana\%2C+Sap+3\%2C+Recap+ by+lqrak

Kasum Beri Waktu Tiga Hari untuk Jokowi Cabut PB Pollycarpus, Rabu, 3 Desember 2014, Tribunnews.com, Jakarta. Diakses tanggal 31 Desember 2014.

Kitab Undang-Undang Hukum Pidana (Book of the Law Penal Code).

Law No. 12 Year 1995 Regarding Correctional.

Law No. 8 of 1981 on the Law of Criminal Procedure.

Menkumham Tak Akan Kaji Ulang Pembebasan Bersyarat Pollycarpus, (Accessed 31 Desember 2014). Tribunnews.com, Jakarta.

Ministerial Decree No. 1999 concerning Assimilation M.01.PK.04-10, Parole And Leave Towards Free.

Ministerial Decree: M. PK.04.10 02. (1990). Guidance Pattern Inmate / Prisoner, Chapter III.

Ministerial Decree: No. M.02-PK.04.10. (1990). Guidance Pattern Prisoners in Chapter VII of the Implementation Guidance Prisoners / Detainees).

Moch. Sueb et al., (2008). In the implementation of parole, Leave Leave Toward Conditional Free and in State Prison Class II B Mamuju, Nurul Farida Basir, 1 M. Shukri Akkub, 2 Muhadar 3 accessed on December 31, 2014 Blueprint for Renewal Implementation of the Correctional System, Ministry of Law and Human Rights Directorate General of Corrections.

Pollycarpus Bebas, Imparsial: Kami Kecewa dengan Pemerintahan Jokowi!, Minggu, 30 November 2014, Republika.co.id, Jakarta. Diakses tanggal 31 Desember 2014.

The ministerial regulation: No. M. 01. PK. 4:10 Year (2007).

The secondary data Correctional Institution Class I Sukamiskin Bandung- West Java.

The Working Group Ake Arif, Principal International Instruments of Human Rights, Jakarta, in 2006. Undang-Undang 1945 (1945 Constitution). 
The Prisoners' Rights Protection in Indonesia Law System of Justice 